JURNAL SEHAT MASADA VOLUME XVI NOMOR 1 Januari 2022 ISSN : 1979-2344

\title{
KAJIAN NARATIF: FAKTOR RISIKO KEJADIAN HIV/AIDS PADA KELOMPOK LSL
}

\author{
Nurvinia Ismayanti ${ }^{1)}$, Yeni Suryamah ${ }^{2)}$ \\ ${ }^{1}$ Program Studi Sarjana Kesehatan Masyarakat, STIKes Dharma Husada, Bandung, Indonesia \\ ${ }^{2}$ Kantor Kesehatan Pelabuhan, Bandung, Indonesia \\ 1nurviniaismyanti@gmail.com
}

\begin{abstract}
Abstrak
Latar Belakang: Berdasarkan data UNAIDS 2020, penderita yang hidup dengan HIV di berbagai negara sebanyak 37,7 juta. Di Indonesia berdasarkan laporan Ditjen P2P, Kemenkes RI Maret 2021 menunjukkan jumlah kasus HIV/AIDS sebanyak 558.618 kasus. Jumlah ODHA (Orang Dengan HIV/AIDS) di Indonesia terus meningkat dan masih terkonsentrasi pada kelompok tertentu diantaranya kelompok Lelaki Seks dengan Lelaki (LSL). Prevalensi HIV pada LSL di Indonesia berdasarkan data Kemenkes periode Januari-Maret 2021 masih cukup tinggi yaitu 26,3\%.

Tujuan: Mengetahui faktor risiko kejadian HIV/AIDS pada kelompok LSL.

Metode: Pencarian literatur melalui database online Google Scholar dan Pubmed rentang tahun 20172021 dengan kata kunci bahasa Indonesia "Faktor Risiko", "HIV/AIDS", "Lelaki Seks dengan Lelaki" dan kata kunci bahasa Inggris "Risk Factors", "HIV/AIDS”," Men Who Have Sex with Men"

Diskusi: Dari dua belas artikel diambil terkait dengan faktor risiko kejadian HIV/AIDS pada kelompok LSL. Faktor risiko kejadian HIV/AIDS pada kelompok LSL antara lain perilaku seks berisiko, karakteristik dan infeksi menular seksual (IMS). Faktor risiko paling banyak pada perilaku seks berisiko yaitu penggunaan kondom.

Kesimpulan: Sebagaian besar penelitian yang telah dilakukan baik dari nasional maupun internasional, menunjukkan bahwa perilaku seks berisiko merupakan faktor risiko yang sangat mempengaruhi kejadian HIV/AIDS pada kelompok LSL terutama dalam konsistensi penggunaan kondom. Dengan demikian, penggunaan kondom saat melakukan hubungan seks disarankan untuk kelompok LSL, sehingga dapat menurunkan angka kejadian HIV/AIDS pada kelompok LSL.
\end{abstract}

Kata Kunci: Faktor Risiko, HIV/AIDS, Lelaki Seks dengan Lelaki

\section{PENDAHULUAN}

Berdasarkan UNAIDS 2020, total penderita HIV di dunia sebanyak 37,7 juta. $^{(1)}$ Laporan perkembangan HIV/AIDS dan PIMS di Indonesia 2021, jumlah kasus HIV sampai dengan Maret 2021 sebanyak 427.201 kasus, sedangkan jumlah kasus AIDS sebanyak 131.417. ${ }^{(2)}$ Pada tahun 2020, populasi kunci dan pasangan seksual menyumbang $65 \%$ dari infeksi HIV, secara global LSL memiliki risiko tertular HIV 25 kali lebih tinggi. ${ }^{(1)}$ Jumlah penderita HIV pada LSL yang ditemukan pada Januari - Maret 2021 sebesar 26,3\%.(2) Data menunjukkan peningkatan persentase kasus HIV sebesar lima kali lipat sejak tahun 2011 untuk LSL. ${ }^{(3)}$ Berbagai hal yang mempengaruhi kejadian HIV pada LSL di Indonesia tidak berbeda dengan yang terjadi di negara lain dan tanpa adanya perubahan signifikan sehingga prevalensi HIV pada LSL terus meningkat. ${ }^{(4)}$ Kajian naratif ini bertujuan untuk mengetahui faktor risiko kejadian HIV/AIDS pada kelompok LSL dan 
JURNAL SEHAT MASADA VOLUME XVI diharapkan dapat menjadi bahan pertimbangan sehingga dapat menurunkan angka kejadian HIV pada kelompok LSL.

\section{METODE}

Penelitian ini menggunakan metode kajian literature riview atau kajian naratif. Pencarian jurnal bersumber pada database online, meliputi Google scholar dan PubMed. Untuk mencari artikel nasional menggunakan kata kunci "Faktor Risiko", "HIV/AIDS", "Lelaki Seks dengan Lelaki" dan untuk mencari artikel internasional menggunakan kata kunci "Risk Factors", "HIV/AIDS”, “Men Who Have Sex with Men”. Adapun kriteria inklusi untuk artikel yang dimasukkan adalah full text, jurnal terakreditasi, jenis penelitian kuantitatif, batas jurnal yang terpublikasi dari tahun 2017 hingga 2021 dan isi jurnal yang jelas yaitu menargetkan LSL.

Sedangkan kriteria eksklusi untuk artikel yang tidak dimasukkan adalah abstrak yang tidak lengkap, responden yang tidak sesuai dan artikel yang tidak terakreditasi.

Jumlah artikel yang teridentifikasi dari mesin pencari artikel sebanyak 966 artikel, yang terdiri dari 386 di PubMed dan 621 di Google Scholar. Selanjutnya artikel dikeluarkan karena duplikasi sebanyak 7 artikel. Sebanyak 959 artikel di skrining berdasarkan judul, hasil skrining ini mengeluarkan 894 artikel yang tidak relevan. Sebanyak 65 artikel di skrining berdasarkan abstrak, hasil skrining ini mengeluarkan 48 artikel. Sebanyak 17 artikel eligibel (memenuhi persyaratan). Setelah analisis kriteria inklusi dan
NOMOR 1 Januari 2022 ISSN : 1979-2344

eksklusi terpilih 12 artikel yang akan dikaji (Gambar 1).

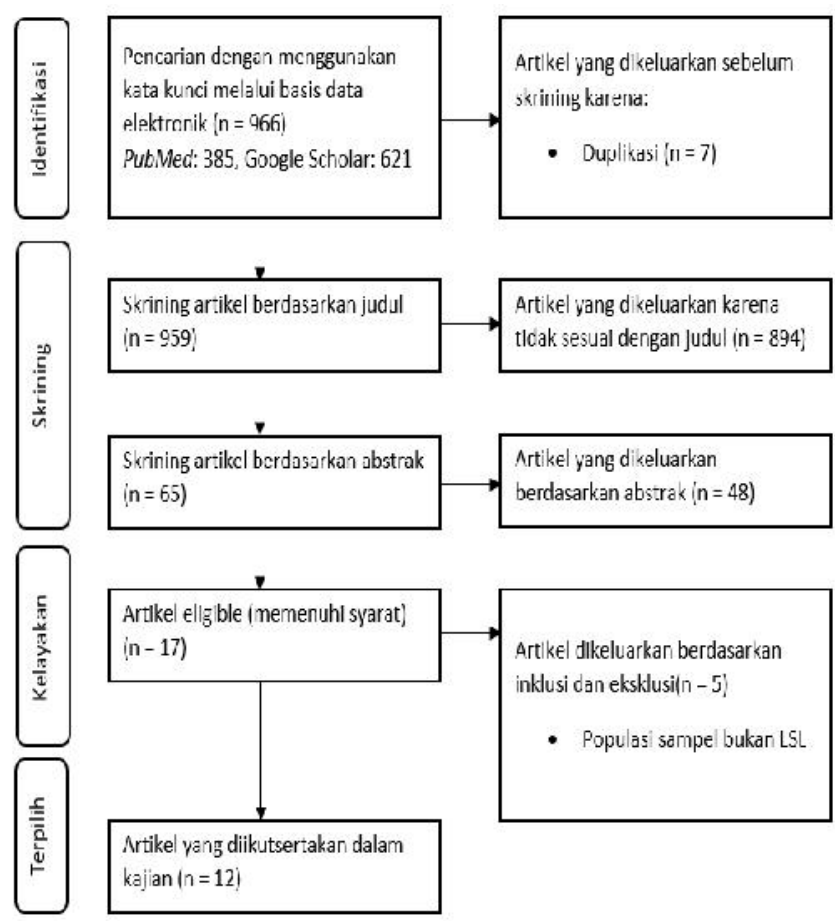

\section{Gambar 1. Diagram Alir Hasil Pencarian}

\section{Literatur}

\section{Diskusi}

Hasil penelusuran database dari Google Scholar dan PubMed didapatkan 12 artikel yaitu 7 artikel nasional dan 5 artikel internasional terpilih melalui kesesuaian skrinning. Maka 12 artikel yang terpilih tersebut dianalisis serta ditinjau kembali, berikut hasil rangkuman penelitian faktor risiko kejadian HIV/AIDS pada Kelompok LSL yang sesuai dengan kriteria inklusi. Berikut ini ringkasan artikel terpilih dengan topik faktor risiko kejadian HIV/AIDS pada kelompok LSL (Tabel 1). 


\section{HASIL}

Tabel 1. Rangkuman Penelitian Faktor Risiko Kejadian HIV/AIDS pada Kelompok LSL

\begin{tabular}{|c|c|c|c|c|c|}
\hline No & Referensi (Penulis) & Variabel & Tujuan Penelitian & $\begin{array}{l}\text { Desain Penelitian } \\
\text { dan Sampel }\end{array}$ & Hasil/Temuan utama/Kesimpulan \\
\hline \multicolumn{6}{|c|}{ Jurnal Nasional } \\
\hline 1. & $\begin{array}{l}\text { Bunga Tiara Carolin, et al } \\
\text { (2020), "Analisis Faktor } \\
\text { Risiko Kejadian Human } \\
\text { Immunodeficiency Virus } \\
\text { (HIV) pada Lelaki Seks } \\
\text { Lelaki (LSL)"(5) }\end{array}$ & $\begin{array}{l}\text { Kejadian HIV, Penggunaan Kondom, } \\
\text { Riwayat IMS, Perilaku Seks Berisiko, } \\
\text { Penggunaan Narkoba Suntik. }\end{array}$ & $\begin{array}{l}\text { Menganalisis faktor-faktor } \\
\text { risiko yang berhubungan } \\
\text { dengan kejadian HIV pada } \\
\text { LSL di hotspot pasar } \\
\text { tengah Kota Bandar } \\
\text { Lampung tahun } 2019 \text {. }\end{array}$ & $\begin{array}{l}\text { - } \text { Cross sectional } \\
\text { - Sampel } \\
\text { berjumlah } 84 \\
\text { responden. }\end{array}$ & $\begin{array}{l}\text { Terdapat hubungan yang signifikan antara } \\
\text { penggunaan kondom }(p=0,001) \text { dan perilaku seks } \\
\text { berisiko }(p=0,002) \text { dengan kejadian HIV pada } \\
\text { LSL. }\end{array}$ \\
\hline 2. & $\begin{array}{l}\text { Fitriana Lupita Sari (2021), } \\
\text { "Analisis Faktor yang } \\
\text { Berhubungan dengan Status } \\
\text { Human Immunodeficiency } \\
\text { Virus (HIV) pada Kelompok } \\
\text { LSL di Kota Bandar } \\
\text { Lampung “(6) }\end{array}$ & $\begin{array}{l}\text { Status HIV, Pengetahuan, Umur pertama } \\
\text { kali seks, Penggunaan Kondom, Gejala } \\
\text { IMS, Frekuensi hubungan seksual, } \\
\text { Jumlah pasangan seks. }\end{array}$ & $\begin{array}{l}\text { Mengungkapkan } \\
\text { determinan kejadian } \\
\text { infeksi HIV/AIDS pada } \\
\text { komunitas LSL. }\end{array}$ & $\begin{array}{l}\text { - Cross sectional } \\
\text { - Sampel } \\
\text { berjumlah } 90 \\
\text { responden. }\end{array}$ & $\begin{array}{l}\text { Variabel yang berhubungan dengan status HIV } \\
\text { pada kelompok LSL di Kota Bandar Lampung } \\
\text { adalah gejala IMS }(\mathrm{p}=0,00 \mathrm{OR}=64,47) \text { dan } \\
\text { jumlah pasangan seksual }(\mathrm{p}=0,013 \mathrm{OR}=3,32) .\end{array}$ \\
\hline 3. & $\begin{array}{l}\text { Rizky Hasby, Mondastri } \\
\text { Korib (2021), "Faktor } \\
\text { Determinan Kejadian HIV } \\
\text { pada Lelaki Seks dengan } \\
\text { Lelaki (LSL) di Indonesia } \\
\text { Tahun 2018,"(7) }\end{array}$ & $\begin{array}{l}\text { HIV, Umur, Status Perkawinan, } \\
\text { Sirkumsisi, Konsistensi Penggunaan } \\
\text { Kondom, Usia Pertama Seks Anal, Seks } \\
\text { Komersial, Pesta Seks, Status Sifilis, } \\
\text { Penggunaan Napza Suntik, Cara } \\
\text { Mendapatkan Kondom, Tes HIV. }\end{array}$ & $\begin{array}{l}\text { Mengetahui faktor } \\
\text { determinan yang } \\
\text { berhubungan dengan } \\
\text { kejadian HIV pada } \\
\text { kelompok LSL. }\end{array}$ & $\begin{array}{l}\text { - Cross sectional } \\
\text { - Sampel } \\
\text { penelitian ini } \\
\text { berjumlah } \\
\text { 4.284 LSL. }\end{array}$ & $\begin{array}{l}\text { Umur }(\mathrm{p}=0,0001) \text {, status perkawinan }(\mathrm{p}=0,0001) \\
\text { sirkumsisi }(\mathrm{p}=0,019) \text {, pesta seks }(\mathrm{p}=0,006) \text {, dan } \\
\text { status sifilis }(\mathrm{p}=0,0001) \text { merupakan determinan } \\
\text { yang berhubungan dengan kejadian HIV pada LSL } \\
\text { dalam penelitian ini. }\end{array}$ \\
\hline 4. & $\begin{array}{l}\text { Laylatul Muawanah, et al } \\
\text { (2019) "Perilaku Seksual } \\
\text { Gay yang Berisiko dengan } \\
\text { Kejadian HIV di Voluntary } \\
\text { Counselling and Testing } \\
\text { (VCT) Puskesmas Batam"(8) }\end{array}$ & $\begin{array}{l}\text { Kejadian HIV, Perilaku seksual gay yang } \\
\text { berisiko }\end{array}$ & $\begin{array}{l}\text { Mengetahui hubungan } \\
\text { perilaku seksual gay yang } \\
\text { berisiko dengan kejadian } \\
\text { HIV }\end{array}$ & $\begin{array}{l}\text { - Cross sectional } \\
\text { - Sampel } \\
\text { berjumlah } 40 \\
\text { orang. }\end{array}$ & $\begin{array}{l}\text { Hasil univariat yang didapatkan perilaku seksual } \\
\text { gay yang berisiko tinggi }(60 \%) \text {, kejadian positif } \\
\text { HIV }(80 \%) \text {. Hasil bivariat yang didapatkan perilaku } \\
\text { seksual gay yang berisiko }(\mathrm{p}=0,004 \mathrm{OR}=17,889) \text {. } \\
\text { Ada hubungan dari perilaku seksual gay yang } \\
\text { berisiko dan kejadian HIV. }\end{array}$ \\
\hline
\end{tabular}


JURNAL SEHAT MASADA VOLUME XVI NOMOR 1

\begin{tabular}{|l|l|}
\hline 5. & $\begin{array}{l}\text { Forman Novrindo Sidjabat, } \\
\text { Henry Setyawan, Muchlis } \\
\text { Au Sofro, Suharyo } \\
\text { Hadisaputro (2017) "Lelaki } \\
\text { Seks Lelaki, HIV/AIDS dan } \\
\text { Perilaku Seksualnya di } \\
\text { Semarang"(9) }\end{array}$ \\
\hline 6. & $\begin{array}{l}\text { Nurul Aryastuti, et al (2019) } \\
\text { "Perilaku Seksual Berisiko } \\
\text { pada Kelompok } \\
\text { Homoseksual di Kota } \\
\text { Bandar Lampung"(10) }\end{array}$ \\
\hline 7. & $\begin{array}{l}\text { Erika Martining Wardani, et } \\
\text { al (2020) "Studi Perilaku } \\
\text { Seks Menyimpang Terhadap } \\
\text { Kejadian HIV Fase Laten } \\
\text { pada Komunitas Lelaki Seks } \\
\text { Lelaki (LSL) di LSM } \\
\text { KOMPEDA Surabaya"(11) }\end{array}$ \\
\hline
\end{tabular}

Memakai obat pembangkit gairah, seks grup, menggunakan alat seks, melakukan kekerasan saat berhubungan seks, usia pasangan seks pertama kali, berhubungan seks dengan laki-laki untuk menerima

bayaran, usia pertama berhubungan seks, konsistensi penggunaan kondom, jumlah pasangan seksual.

Umur, Status perkawinan, Umur pertama kali hubungan seksual, Pasangan seks pertama kali, Penggunaan kondom seks pertama kali, Jenis kelamin pasangan tetap, Penggunaan kondom/pelicin, Teknik seksual, Penggunaan kondom sebulan terakhir, Seks anal sesama jenis, Seks dengan jenis kelamin lainnya.

Usia, Sirkumsisi, Seks dengan lebih dari 1 orang, Penggunaan kondom, Seksual anal, Seksual oral, Bergantian memasukkan jari ke anus, Bergantian memasukkan jari ke anus pasangan, Rimming, Interfemoral coitus, Saling bergantian alat bantu seks

Mengetahui faktor risiko kelompok LSL. yang berhubungan dengan kejadian HIV/AIDS pada

\begin{tabular}{l|l|} 
& responden. \\
& $\bullet$ Cross sectional \\
\hline $\begin{array}{l}\text { Mengetahui perilaku } \\
\text { seksual berisiko pada } \\
\text { kelompok homoseksual di } \\
\text { Kota Bandar Lampung. }\end{array}$ & $\bullet \begin{array}{l}\text { Sampel } \\
\text { sejumlah 86 } \\
\text { orang. }\end{array}$ \\
\hline $\begin{array}{l}\text { Mengetahui gambaran } \\
\text { perilaku seks menyimpang } \\
\text { terhadap kejadian HIV } \\
\text { fase laten pada komunitas } \\
\text { LSL }\end{array}$ & $\begin{array}{l}\text { Deskriptif } \\
\text { survey } \\
\text { Sampel yang } \\
\text { digunakan } \\
\text { adalah 65 } \\
\text { orang. }\end{array}$ \\
\hline
\end{tabular}

\section{Jurnal Internasional}

\begin{tabular}{l|l|l}
\hline 8. & Elia J. Mmbaga, et al (2018) & Kelompok umur, Status perkawinan,
\end{tabular}

"HIV Prevalence and Associated Risk Factors Among Men Who Have Sex With Men in Dar es Salaam, Tanzania",(12)

9. $\quad$ Robert Garofalo, et al (2017), "Incidence of HIV Infection and Sexually Transmitted Infections and Related Risk Factors Among Very Young Men Who Have
Berhubungan seks dengan wanita, Seks berkelompok, Menggunakan kondom selama seks kelompok terakhir,

Menggunakan Obat selama hubungan seks, Menggunakan alkohol selama hubungan seks, Sifilis, Menggunakan pelumas berbahan dasar air bekas selama seks

Status HIV, Umur, Hubungan seks dengan pasangan positif HIV, Seks transaksional baru-baru ini, Jumlah pasangan, Hubungan seks anal yang dilindungi, Hubungan seks dengan pasangan pria dengan status HIV tidak

\section{Menyelidiki tingkat} penyebaran HIV dan perilaku risiko guna menyediakan data spesifik penduduk dan konteks untuk menginformasikan pemrograman

- Cross sectional

- Sampel penelitian ini berjumlah 753 LSL
Menggambarkan faktor-

faktor yang berkait dengan infeksi baru.
- Studi longitudinal

- Sampel berjumlah 450

Januari 2022 ISSN : 1979-2344

- Kasus-kontrol Usia muda berhubungan seksual $(p=0,001)$, tidak

- Sampel dalam konsisten menggunakan kondom $(\mathrm{p}=0,004)$ dan penelitian ini perilaku hubungan seksual $(\mathrm{p}=<0,001)$ merupakan berjumlah 108 faktor yang berhubungan dengan risiko HIV/AIDS pada kelompok LSL.

Usia pertama melakukan hubungan seksual pada kelompok LSL adalah 76,7\% pada kelompok usia remaja akhir dengan sesama pria $(69,8 \%)$. Perilaku penggunaan kondom pada kelompok LSL selalu menggunakan kondom $(59,4 \%)$, dengan pasangan tetap tidak pernah menggunakan kondom $(30 \%)$, jenis kelamin lainnya tidak pernah menggunakan kondom $(47,6 \%)$.

Usia remaja akhir 17-25 tahun $(58,5 \%)$ dan mayoritas sudah disirkumsisi (97\%). Melakukan hubungan seksual dengan lebih satu orang $(52, \%)$, penggunaan kondom (40\%). Penelitian dapat disimpulkan bahwa perilaku seksual menyimpang pada kelompok LSL di LSM KOMPEDA Surabaya tergolong beresiko menularkan HIV/AIDS.

Kira-kira setengah $(51,8 \%)$ adalah remaja, sedangkan $10 \%$ lebih tua dari 35 tahun. Mayoritas masih lajang $(83,2 \%)$ dan yang sudah menikah $(6,3 \%)$. Hampir sepertiga dari responden memiliki anak $(29,5 \%)$, mayoritas hanya memiliki 1 anak $(72 \%)$.

Peristiwa HIV (95\%CI 2,80-6,04). Insiden HIV kumulatif selama 24 bulan masa tindak lanjut adalah 7,32\% (95\% CI 5,05-10,57). Dalam analisis multivariat, riwayat tes HIV dan hubungan seks dengan pasangan positif HIV dikaitkan dengan infeksi peningkatan risiko infeksi HIV. 
JURNAL SEHAT MASADA

VOLUME XVI

NOMOR 1

Januari 2022

ISSN : 1979-2344

\begin{tabular}{|c|c|c|c|c|c|}
\hline & Sex with Men"(13) & $\begin{array}{l}\text { diketahui, Penggunaan alkohol dan zat } \\
\text { terlarang selama hubungan seks. }\end{array}$ & & responden. & \\
\hline 10. & $\begin{array}{l}\text { Thana Khawcharoenporn, et } \\
\text { al (2019), "HIV Risk, Risk } \\
\text { Perception and Uptake of } \\
\text { HIV Testing and Counseling } \\
\text { among Youth Men Who } \\
\text { Have Sex with Men } \\
\text { Attending a Gay Sauna"(14) }\end{array}$ & $\begin{array}{l}\text { Status perkawinan, Tingkat pengetahuan, } \\
\text { Jumlah pasangan seksual yang berbeda } \\
\text { selama } 1 \text { bulan terakhir, Jumlah } \\
\text { pasangan seksual baru selama } 1 \text { bulan } \\
\text { terakhir, Penggunaan kondom saat seks, } \\
\text { Bertukar seks dengan uang, Minum } \\
\text { alkohol saat seks dalam waktu } 30 \text { hari, } \\
\text { Menggunakan narkoba saat seks dalam } \\
\text { waktu } 30 \text { hari, Riwayat IMS. }\end{array}$ & $\begin{array}{l}\text { Menilai risiko HIV, } \\
\text { perilaku berisiko, } \\
\text { pengetahuan pencegahan } \\
\text { penularan HIV, persepsi } \\
\text { risiko HIV, infeksi HIV } \\
\text { dan keterlibatan perawatan } \\
\text { di antara LSL muda } \\
\text { dibandingkan dengan LSL } \\
\text { lain dari hotspot. }\end{array}$ & $\begin{array}{l}\text { - } \text { Kohort } \\
\text { prospektif } \\
\text { - Sampel yang } \\
\text { digunakan } \\
\text { dalam } \\
\text { penelitian ini } \\
\text { sebanyak } 358 \\
\text { LSL. }\end{array}$ & $\begin{array}{l}\text { Dibandingkan dengan LSL lain, LSL remaja } \\
\text { memiliki median jumlah pasangan seksual seumur } \\
\text { hidup yang secara signifikan lebih tinggi ( } 2 \text { (IQR 1- } \\
\text { 9) vs. 1 (IQR } 0-1) \text {; p < 0,001), lebih mungkin untuk } \\
\text { menukar seks demi uang ( } 44 \% \text { vs. } 9 \% \text {; }<0,001) \text {. } \\
\text { Tingkat penggunaan kondom yang terakhir untuk } \\
\text { seks anal, oral dan vagina rendah dan tidak berbeda } \\
\text { secara signifikan antara remaja dan LSL lainnya } \\
(51 \% \text { vs. } 61 \%, 26 \% \text { vs. } 35 \% \text { dan } 72 \% \text { vs. } 61 \%) \text {. }\end{array}$ \\
\hline 11. & $\begin{array}{l}\text { Tonia Poteat, et al (2017), } \\
\text { "HIV prevalence and } \\
\text { behavioral and psychosocial } \\
\text { factors among transgender } \\
\text { women and cisgender men } \\
\text { who have sex with men in } 8 \\
\text { African countries"(15) }\end{array}$ & $\begin{array}{l}\text { Usia, Pekerjaan, Interseks, Negara, } \\
\text { Stigma, Mental health, Alkohol dan } \\
\text { pengguna zat, Perilaku seks, Akses } \\
\text { kondom /pelumas, Infeksi seksual } \\
\text { menular, HIV, Jenis kelamin, Seks anal } \\
\text { reseptif tanpa kondom, Kekerasan }\end{array}$ & $\begin{array}{l}\text { mengkarakterisasi faktor } \\
\text { risiko psikososial dan } \\
\text { perilaku, dan membedakan } \\
\text { epidemiologi HIV di } \\
\text { antara perempuan } \\
\text { transgender dari yang di } \\
\text { antara cis-LSL }\end{array}$ & $\begin{array}{l}\text { - } \text { Cross sectional } \\
\text { - Sampel dalam } \\
\text { penelitian ini } \\
\text { sebanyak } 4.586 \\
\text { responden. }\end{array}$ & $\begin{array}{l}\text { Jika disesuaikan dengan usia, seks anal reseptif } \\
\text { kondom, depresi, stigma interpersonal, stigma } \\
\text { penegakan hukum, dan kekerasan, dan interaksi } \\
\text { gender dengan seks anal reseptif tanpa kondom, } \\
\text { kemungkinan infeksi HIV untuk wanita transgender } \\
\text { adalah } 2,2 \text { kali lebih besar daripada cis-LSL }(95 \% \\
\text { CI 1,65-2,8, p <0,001). }\end{array}$ \\
\hline 12. & $\begin{array}{l}\text { Isabel Hernandez, et al } \\
\text { (2017), "Risk Factors } \\
\text { Associated With HIV } \\
\text { Among Men Who Have Sex } \\
\text { With Men (MSM) in } \\
\text { Ecuador"(16) }\end{array}$ & $\begin{array}{l}\text { Status HIV, Umur, Status perkawinan, } \\
\text { Memiliki pasangan tetap, Berhubungan } \\
\text { seks dengan wanita } 30 \text { hari terakhir, } \\
\text { Berhubungan seks dengan laki-laki } \\
\text { dalam } 30 \text { hari terakhir, Terpaksa } \\
\text { melakukan seks reseptif } 30 \text { hari terakhir }\end{array}$ & $\begin{array}{l}\text { Menentukan prevalensi } \\
\text { HIV di antara LSL di } \\
\text { wilayah Ekuador dan } \\
\text { menilai pengetahuan dan } \\
\text { perilaku berisiko HIV }\end{array}$ & $\begin{array}{l}\text { - } \text { Cross sectional } \\
\text { - Sampel } \\
\text { sebanyak } 307 \\
\text { responden. }\end{array}$ & $\begin{array}{l}\text { Peserta yang memiliki banyak pasangan seksual } \\
\text { laki-laki memiliki peluang } 3,7 \text { kali lebih tinggi } \\
\text { untuk dites positif HIV. Mereka juga telah } \\
\text { mengurangi penggunaan kondom. Peserta yang } \\
\text { dipaksa melakukan seks reseptif anal memiliki } \\
\text { kemungkinan } 3 \text { kali lebih tinggi untuk dites positif } \\
\text { HIV. }\end{array}$ \\
\hline
\end{tabular}

Jurnal Penelitian Kesehatan STIKes Dharma Husada Bandung 
JURNAL SEHAT MASADA VOLUME XVI Berdasarkan kajian naratif yang dilakukan, penulis membedakan faktor risiko kejadian HIV/AIDS pada LSL yaitu perilaku seks berisiko, demografi dan infeksi menular seks.

\section{Perilaku Seks Berisiko}

Perilaku seksual berisiko merupakan seks anal dan oral yang tidak aman/tidak menggunakan kondom memungkinkan terjadinya pertukaran cairan tubuh sehingga Selain itu perilaku LSL yang memiliki banyak pasangan sangatlah berisiko tinggi untuk terjadinya transmisi HIV dan memungkinkan untuk menaikkan angka HIV pada kelompok LSL dikarenakan LSL dengan HIV lebih sering berganti pasangan dan memiliki seks partner lebih dari satu yang tidak terinfeksi HIV dan kelompok LSL lebih sering tidak mengetahui status HIV pasangan seksualnya. Berdasarkan artikel yang terpilih variabel yang termasuk perilaku seks berisiko adalah penggunaan kondom, jumlah pasangan seks, pesta seks, seks untuk uang, dan berhubungan seks dengan orang yang positif HIV.

Dalam berhubungan seksual akan terjadi perlukaan pada jaringan sehingga melalui luka tersebut virus dapat masuk dan menginfeksi tubuh. Untuk itu sangat penting pemakaian kondom secara konsistensi, kondom jika penggunaannya konsistensi dan benar dapat menurunkan risiko penularan HIV, termasuk penularan penyakit melalui sekresi genital. Hanya saja jika penggunaan kondom konsistensi namun tidak benar dan tidak hygiene dapat menyebabkan sangat mudah untuk mentransmisi HIV.

NOMOR 1 Januari 2022 ISSN : 1979-2344 bertambahnya risiko. ${ }^{(5)}$ Pada penelitian yang dilakukan oleh Forman Novrindo Sidjabat dkk, menyatakan bahwa LSL yang tidak konsisten menggunakan kondom saat melakukan hubungan seksual memiliki risiko 3,40 kali mengalami kejadian HIV/AIDS dibandingkan dengan LSL yang konsistensi menggunakan kondom saat melakukan hubungan seksual. ${ }^{(9)}$ Sebagian besar seorang homoseksualitas rata-rata memilih 6-7 pasangan, mereka memiliki lebih dari satu pasangan hubungan seks dan bergonta-ganti pasangan seks. ${ }^{(11)}$ Salah satu artikel menyatakan bahwa LSL dengan jumlah pasangan > 1 beresiko 3,32 kali mengalami kejadian HIV dibandingkan dengan LSL yang tidak memiliki pasangan seksual atau hanya 1 pasangan seksual. ${ }^{(6)}$

Pesta Seks tertutup adalah sebuah situasi berisiko HIV yang muncul di kelompok LSL. Pada tahun 2009, sebuah wawancara mendalam diketahui bahwa 103 LSL melaporkan mengikuti setidaknya satu kali pesta seks di Masschusetts setahun terakhir, dan sepertiga (32\%) dari sampel melaporkan tidak menggunakan kondom saat melakukan seks pada pesta seks terakhir. Pesta seks yang diikuti lebih dari 2 orang tersebut berisiko meningkatkan penularan akibat bergantiganti pasangan dan seks tanpa menggunakan kondom. ${ }^{(7)}$ LSL remaja memiliki pasangan seksual yang lebih berbeda dan baru secara signifikan dalam sebulan terakhir dan proporsi yang lebih tinggi dari mereka yang menukar seks dengan uang dan memiliki pasangan seksual yang menukar seks dengan Jurnal Penelitian Kesehatan STIKes Dharma Husada Bandung 
JURNAL SEHAT MASADA VOLUME XVI uang dibandingkan dengan LSL lain. ${ }^{(14)}$ Seks dengan pasangan positif HIV memiliki risiko 5,48 kali mengalami kejadian HIV/AIDS dibandingkan dengan LSL yang tidak melakukan seks dengan pasangan positif HIV. ${ }^{(7)}$

\section{Demografi}

Berdasarkan artikel yang terpilih variabel yang termasuk kategori demografi adalah umur, status perkawinan, dan sirkumsisi. Semakin bertambah usia LSL perilaku seks semakin berisiko. Pada penelitian ini umur LSL 25 memiliki risiko 1,82 kali mengalami kejadian HIV dibandingkan dengan umur $<25$ tahun. ${ }^{(7)}$ LSL yang belum kawin atau tidak memiliki pasangan yang sah/resmi cenderung lebih berisiko tertular HIV karena tingkat kehati-hatian yang kurang dalam berhubungan seks karena tidak memiliki tanggung jawab dan memiliki lebih banyak waktu untuk mencari pasangan baru (berganta-ganti pasangan), LSL yang belum menikah dengan perempuan memiliki risiko 6 kali mengalami kejadian HIV dibandingkan dengan LSL yang sudah menikah dengan perempuan. ${ }^{(7)}$ Sirkumsisi diketahui sebagai salah satu upaya pencegahan penularan HIV, sehingga tidak melakukannya terbukti dari penelitian ini berisiko 1,23 kali untuk kejadian HIV. Hubungan tersebut terbukti secara signifikan semakin kuat terutama pada LSL di negara low middle income (pendapatan menengah kebawah) dibandingkan dengan LSL di negara pendapatan tinggi. Penelitian randomized controlled trial (RCT) untuk melihat
NOMOR 1 Januari 2022 ISSN : 1979-2344 efektifitas sirkumsisi dalam mencegah infeksi HIV pertama kali dilakukan pada laki-laki heteroseksual di Afrika Selatan. Kemudian pada tahun 2010-2011 dilakukan survei lanjutan untuk evaluasi proyek Bophelo Pele (2007-2008) dengan 3.338 sampel laki-laki heteroseksual usia 15-49 tahun, didapatkan hasil bahwa pelaksanaan Voluntary Medical Male Circumcision (VMMC) atau sirkumsisi medis pada laki-laki secara sukarela berhubungan signifikan terhadap penurunan HIV di masyarakat. ${ }^{(7)}$

\section{Infeksi Menular Seksual (IMS)}

Berdasarkan artikel terpilih yang termasuk infeksi menular seks (IMS) adalah status sifilis dan gejala IMS. Status sifilis positif pada penelitian ini terbukti berhubungan kuat dengan kejadian HIV. Infeksi sifilis, terutama infeksi sifilis aktif diantara LSL sering diasosiasikan dengan perilaku seks berisiko dan berkontribusi pada transmisi HIV pada komunitas tersebut. Menurut penelitian di China berdasarkan 15 lokasi tempat berkumpul LSL mencari pasangan, LSL dengan sifilis positif memiliki prevalensi HIV yang lebih tinggi (13,75\%) dibandingkan LSL yang tidak memiliki hasil tes sifilis dan hasil tes sifilis negatif. ${ }^{(7)}$ LSL dengan gejala IMS beresiko 64,47 kali mengalami kejadian HIV dibandingkan dengan responden yang tidak mengalami gejala IMS. IMS akan menjadi pintu masuk bagi penularan HIV karena adanya cairan tubuh atau darah pada luka akibat IMS. Walaupun setiap orang memiliki gejala yang 
JURNAL SEHAT MASADA VOLUME XVI berbeda tergantung pada kondisi dan tahapan infeksinya. ${ }^{(6)}$

Berdasarkan uraian di atas kategori perilaku seks berisiko merupakan faktor risiko kejadian HIV/AIDS pada kelompok LSL paling berisiko dibandingkan dengan kategori demografi dan infeksi menular seksual (IMS). Pada kategori perilaku seks berisiko paling banyak yaitu penggunaan kondom dengan jumlah artikel sebanyak 9 artikel yang menyatakan penggunaan kondom berhubungan dengan kejadian HIV/AIDS pada kelompok LSL. Pada kategori demografi paling banyak yaitu umur dengan jumlah artikel sebanyak 4 artikel yang menyatakan umur berhubungan dengan kejadian HIV/AIDS pada kelompok LSL. Sedangkan, pada kategori Infeksi menular seksual (IMS) hanya 1 artikel yang menyatakan bahwa status sifilis dan gejala IMS berhubungan dengan kejadian HIV/AIDS pada kelompok LSL.

Kajian naratif ini juga memiliki keterbatasan dan kelebihan. Keterbatasan yang ditemui saat penulisan kajian naratif, yaitu dari dua belas artikel yang diambil sebanyak delapan artikel menggunakan desain studi cross sectional. Kelemahan desain studi cross sectional yaitu kurang efektif, memerlukan ukuran sampel yang lebih besar untuk memberikan akurasi, memungkinkan terjadinya bias yang dapat mempengaruhi hasil. Beberapa artikel juga memiliki jumlah responden yang sedikit atau yang jumlahnya kurang dari setengah populasi sehingga masih kurang menggambarkan keadaan yang
NOMOR 1 Januari 2022 ISSN : 1979-2344 sebenarnya dan ada juga yang tidak diketahui jumlah populasi sehingga tidak dapat dilihat apakah artikel cukup menggambarkan atau tidak. Hampir semua artikel melakukan uji statistik hanya sampai bivariat saja, sehingga hanya dapat melihat ada hubungan atau tidak antara variabel independen dan variabel dependen. Kelemahannya tidak dapat melihat variabel yang mana yang paling dominan atau kuat diantara variabel lainnya. Keterbatasan lainnya yaitu hanya mengambil artikel dari database Google Scholar dan PubMed sehingga ada artikel yang terlewatkan. Selain keterbatasan, dua belas artikel terpilih juga memiliki kelebihan yaitu salah satu artikel menggunakan desain penelitian kohort sehingga mengurangi terjadinya recall bias, dan beberapa artikel uji statistik sampai dengan multivariat sehingga dapat melihat variabel dominan diantara variabel yang berhubungan. Dengan melihat keterbatasan dan kelebihan pada dua belas artikel ini memungkinkan untuk memberikan rekomendasi untuk peneliti selanjutnya agar melakukan penelitian dan penulisan jurnal dengan tepats sehingga keterbatasan di artikel sebelumnya berkurang.

\section{KESIMPULAN}

Sebagaian besar penelitian yang telah dilakukan baik dari nasional maupun internasional, menunjukkan bahwa perilaku seks berisiko merupakan faktor risiko yang sangat mempengaruhi kejadian HIV/AIDS pada kelompok LSL terutama dalam 
JURNAL SEHAT MASADA VOLUME XVI konsistensi penggunaan kondom. Faktor risiko kejadian HIV/AIDS pada kelompok LSL yang ada yaitu penggunaan kondom, umur, jumlah pasangan seks, status perkawinan, pesta seks, gejala IMS, sirkumsisi, status sifilis, berhubungan seksual dengan pasangan yang positif HIV, dan melakukan hubungan seksual untuk uang. Dengan demikian, penggunaan kondom saat melakukan hubungan seks disarankan untuk kelompok LSL, sehingga dapat menurunkan angka kejadian HIV/AIDS pada kelompok LSL. Untuk pemerintah disarankan agar meningkatkan kemampuan pencegahan HIV/AIDS pada kelompok LSL dengan melalui edukasi. Untuk penyedia layanan kesehatan dapat meningkatkan pelayanan dengan meningkatkan program skrining HIV/AIDS pada kelompok LSL dan mengadakan konseling perubahan perilaku serta dukungan psikososial. Untuk penelitian lanjutan dapat meneliti lebih lanjut mengenai kepatuhan penggunaan kondom saat melakukan hubungan seks pada kelompok LSL.

\section{REFERENSI}

1. UNAIDS. Fact Sheet 2021 Global HIV Statistics. End AIDS epidemic. 2021;(June):1-3.

2. Direktur Jenderal P2P. Laporan Perkembangan HIV AIDS \& Penyakit lnfeksi Menular Seksual (PIMS) Triwulan I Tahun 2021. Kementeri Kesehat RI [Internet]. 2021;4247608(021):613-4. Available from:

https://siha.kemkes.go.id/portal/perkemb angan-kasus-hiv-aids_pims\#
NOMOR 1 Januari 2022 ISSN : 1979-2344

3. KemenKes RI. Rencana Aksi Nasional Pencegahan Dan Pengendalian HIV AIDS dan PIMS Di Indonesia Tahun 2020-2024. Kementeri Kesehat Republik Indones. 2020;1-188.

4. Hasby R, Sudaryo MK. Faktor Determinan Kejadian HIV pada Lelaki Seks dengan Lelaki (LSL) di Indonesia Tahun 2018 [Determinant Factors of HIV Incidence in Men Sex with Men (MSM) in Indonesia in 2018]. Promot J Kesehat Masy. 2021;11(01):1-9.

5. Tiara Carolin B, Suprihatin, P.K AM. Analisis Faktor Risiko Kejadian Human Immunodeficiency Virus (HIV) Pada Lelaki Seks Lelaki (LSL). core.ac.uk [Internet]. 2020 [cited 2021 Nov 17];6(2):141-7. Available from: https://core.ac.uk/download/pdf/328113 521.pdf

6. Sari FL. Analisis Faktor Yang Berhubungan dengan Status Human Immunodeficiency Virus (HIV) pada Kelompok LSL di Kota Bandar Lampung. rcipublisher.org [Internet]. 2021 [cited 2021 Nov 17];1:2774-5244. Available from: http://rcipublisher.org/ijohm/index.php/i johm/article/view/73

7. Hasby R, Korib M. Faktor Determinan Kejadian HIV pada Lelaki Seks dengan Lelaki (LSL) di Indonesia Tahun 2018. jurnal.unismuhpalu.ac.id [Internet]. [cited 2021 Nov 17]; Available from: https://www.jurnal.unismuhpalu.ac.id/in dex.php/PJKM/article/view/1511

8. Muawanah L, ... LS-ZK, 2020 undefined. Gay's Sexual Behavior that Rises The Event of HIV in Voluntary Counselling and Testing (VCT) Puskesmas Batam. ejurnal.univbatam.ac.id [Internet]. 2018 [cited 2021 Nov 17]; Available from: http://ejurnal.univbatam.ac.id/index.php/ Keperawatan/article/view/326

9. Sidjabat FN, Setyawan H, Sofro MA, Hadisaputro S. Lelaki seks lelaki, HIV/AIDS dan perilaku seksualnya di Semarang. researchgate.net [Internet]. 2017 [cited 2021 Nov 17]; Available 
JURNAL SEHAT MASADA VOLUME XVI from:

https://www.researchgate.net/profile/For man-

Sidjabat/publication/322592829_LELA KI_SEKS_LELAKI_HIVAIDS_DAN_ PERILAKU_SEKSUALNYA_DI_SEM ARANG_Men_Who_Have_Sex_with_ Men_HIV_and_Their_Sexual_Behaviou r_in_Semarang/links/5a618bc8a6fdccb6 1c5030d2/LELAKI-SEKS-LELAK

10. Aryastuti N, Febriani CA, Perdana AA. Perilaku Seksual Berisiko pada Kelompok Homoseksual di Kota Bandar Lampung. J Dunia Kesmas. 2019;8:219_ 25 .

11. Wardani EM, Setiawan AH, Bistara DN, Keperawatan J, Masyarakat K, Cendekia $\mathrm{S}$, et al. Studi Perilaku Seks Menyimpang Terhadap Kejadian HIV Fase Laten Pada Komunitas Lelaki Seks Lelaki (LSL) Di LSM Kompeda Surabaya. jurnal.stikescendekiautamakudus.ac ... [Internet]. [cited 2021 Nov 17]; Available from: http://www.jurnal.stikescendekiautamak udus.ac.id/index.php/stikes/article/view/ 519

12. Mmbaga EJ, Moen $\mathrm{K}$, Leyna GH, Mpembeni R, Leshabari MT. HIV Prevalence and Associated Risk Factors Among Men Who Have Sex With Men in Dar es Salaam, Tanzania. J Acquir Immune Defic Syndr. 2018;77(3):243-9.

13. Garofalo R, Hotton AL, Kuhns LM, Gratzer B, Mustanski B. Incidence of HIV infection and Sexually Transmitted Infections and Related Risk Factors among Very Young Men Who Have Sex with Men. Physiol Behav. 2017;176(1):100-106.

14. Khawcharoenporn $\mathrm{T}$, Mongkolkaewsub S, Naijitra C, Khonphiern W, Apisarnthanarak A, Phanuphak N. HIV risk, risk perception and uptake of HIV testing and counseling among youth men who have sex with men attending a gay sauna. AIDS Res Ther. 2019 Jun $12 ; 16(1)$.

Jurnal Penelitian Kesehatan STIKes Dharma Husada Bandung
NOMOR 1 Januari 2022 ISSN : 1979-2344

15. Poteat T, Ackerman B, Diouf D, Ceesay $\mathrm{N}$, Mothopeng T, Odette KZ, et al. HIV prevalence and behavioral and psychosocial factors among transgender women and cisgender men who have sex with men in 8 African countries: A cross-sectional analysis. PLoS Med. 2017;14(11):1-17.

16. Hernandez I, Reina-Ortiz M, Johnson A, Rosas C, Sharma V, Teran S, et al. Risk Factors Associated With HIV Among Men Who Have Sex With Men (MSM) in Ecuador. Am J Mens Health. 2017 Sep 1;11(5):1331-41. 